\title{
Imagining Peace(s) in Colombia. Between Negotiations, Policies, and Resisting Narratives $^{1}$
}

\section{Imaginando paz(ces) en Colombia. Entre negociaciones, políticas y narrativas de resistencia}

\author{
Ana Isabel Rodríguez Iglesias ${ }^{2}$ \\ Universidade de Coimbra (Portugal)
}

Recibido: 17-12-18

Aprobado: 06-11-19

\section{Resumen}

Este artículo explora la pluralidad de significados de la paz y sus encuentros para comprender los desafíos futuros en la fase de consolidación de la paz en Colombia. A través del análisis del discurso y sistematización de los principales discursos sobre la paz en el debate público en Colombia, se muestran los puntos de proximidad y distancia entre ellos. En particular, el texto deconstruye las visiones hegemónicas de la paz al contrastarlas con las propuestas alternativas o críticas de paz. El documento concluye que las negociaciones de paz fueron una oportunidad para darle a la paz un significado compartido por la gran mayoría de la sociedad colombiana. Sin embargo, por el contrario, la discusión sobre lo que significa y conlleva la paz ha permanecido abierta después de la firma del acuerdo de paz y, por lo tanto, está afectando su implementación.

Palabras-clave: Paz(ces), narrativas, diálogos de paz, resistencia, Colombia.

\footnotetext{
${ }^{1}$ The elaboration of this article was funded by the FCT (Fundação para a Ciência e a Tecnologia) of Portugal with national and European funds of the European Social Fund.

2 (airodrigueziglesias@gmail.com) Ana I Rodríguez Iglesias is a PhD candidate in International Politics and Conflict Resolution from the University of Coimbra (2015-2020). She has been awarded the Fulbright scholarship for her MA in Latin American Studies from Georgetown University, Washington DC, and La Caixa scholarship for her MA studies in International Relations at the University CEU San Pablo, Madrid. She is currently working as associate professor at the International University of Catalonia in Barcelona and member of the Research group GLOBALCODES of the Blanquerna School of Communication, University Ramón Llull in Barcelona.

ORCID: https://orcid.org/0000-0002-5066-3190.
} 


\begin{abstract}
This article explores the plurality of meanings of peace and their encounters in order to understand the challenges ahead in the peacebuilding phase in Colombia. By mapping and systematizing the main discourses around peace in the public debate in Colombia, it shows the points of proximity and distance among them based on discourse analysis. In particular, the text deconstructs the hegemonic visions of peace by contrasting them with the alternative or critical proposals of peace. The paper concludes that the peace negotiations were a window of opportunity to give peace a meaning that was shared by a great majority of the Colombian society. Rather, on the contrary, the discussion about what peace means and entails has remained open after the peace agreement was signed and thus is affecting its implementation.
\end{abstract}

Key-words: Peace(s), Narratives, Peace Talks, Resistance, Colombia.

\title{
Introduction
}

Over the course of four years, the government of Juan Manuel Santos of Colombia and the guerrilla FARC-EP met in Havana, Cuba to talk about a peace deal. These talks were based on different premises: for the government, the peace talks were the result of a successful military campaign against the insurgent group that had taken place over the past eight years; for the guerilla, the process was a success because they were not defeated militarily and they were recognized as valid interlocutors in the search for political solutions to the conflict. The signing of the Final Peace Agreement between these two parties, signed in August 2016, brought an end to one of the longest protracted armed conflicts in the world and represented a transcendental moment in the history of Colombia.

Most of the conversations that took place during the negotiations and after the approval of the Agreement revolved around the implementation of the Agreement, yet little attention was paid to what the different actors understood by peace. The rejection of the Peace Agreement in the referendum that was held in October of 2016, along with the congressional discussions that took place afterwards to prepare the legal framework of the agreement, showed that for the different sectors of society there was no common ground over the meaning of the term and that the discussions had not been closed during the peace talks. On the contrary, the peace talks established a lowest common denominator to end the conflict and to start building peace, but they did not fix a common interpretation of peace. Between what the authors of the document wrote and what the different audiences interpreted, there is a whole range of possibilities. 
This article explores the plurality of meanings of peace and their encounters in order to understand the challenges ahead in the peacebuilding phase in Colombia. By mapping and systematizing the main discourses around peace in the public debate in Colombia, it shows the points of proximity and distance among them based on discourse analysis. In particular, the text deconstructs the hegemonic visions of peace by contrasting them with the alternative or critical proposals of peace. The paper concludes that the peace negotiations were a window of opportunity to give peace a meaning that was shared by a great majority of the Colombian society. Rather, on the contrary, the discussion about what peace means and entails has remained open after the peace agreement was signed and thus is affecting its implementation.

This paper follows an interpretative methodology based on intertextuality and discourse analysis. The article puts in dialogue different studies of peace and conflict in Colombia, public views, narratives, interpretations, as well as interviews the author has conducted on the ground with the main actors of the peacemaking process. This paper is part of a larger research project in which the author spent fifteen months in different places of Colombia (including Bogotá and the department of Chocó) conducting more than one hundred interviews and accompanying the implementation of the peace deal through ethnographic work. In this paper, the author has quoted some of these interviews that took place with high level actors of the peace process and used others as background information for the analysis.

\section{A poststructuralist approach: Peace as an empty signifier}

This paper is designed as a dialogue with poststructuralism and its reflection on 'how knowledge, truth, and meaning are constituted' (Der Derian and Shapiro 1989: xiii) and reconstructed in an ongoing process, rejecting any meaning, truth and knowledge as essentialist or universal. Poststructuralism rejects the notion of the concept of peace 'as ontologically stable, in terms of representing an objective truth (plausible or not), legitimating the exercise of power, and representing a universal ethic' (Richmond 2008: 5). This theoretical/ methodological approach does not offer an alternative ontology or theory, but rather, it uncovers how discourses of peace become naturalized and normalized through hegemonic practices.

This paper starts with the premise that the concept of peace is polysemic, subject to interpretation, and never closed. Peace is not a universal phenomenon or totality. Rather, peace is the product of social relations and the articulation of different discourses in a particular historical context. Taking the contingency and historicity of the meaning of peace into account, this conceptual proposal draws from the discourse theory of Laclau and Mouffe $(1985,2005)$ to 
understand how the meaning of peace is temporally fixed in a hegemonic practice, how the hegemonic articulations exclude other alternatives, and also how in turn this aforementioned contingency allows for change, contestation, and re-articulation. Thus, peace is studied as an empty signifier whose meaning is constructed on an ongoing basis according to dynamics of power and resistance. Power struggles of meaning-making tend to fix a hegemonic articulation of the meaning, but this act is always contingent and temporary, and subject to alterations. ${ }^{3}$

From this point of departure, this paper explores the multiplicity of interpretations of peace that were present in the public debate and how their encounter happened at different levels: between the government and the FARC, between the peace delegations and the opposition, as well as between political elites and social movements. This plurality of discourses about peace, in turn, are a reflection of the multiplicity of understandings of war, conflict, and violence. They are also rooted in some other peace discourses that got their meaning in previous peace dialogues/talks, peace movements, and even warrelated policies.

\section{Peace(s) in dispute}

Drawing from a literature review on the Colombian conflict and peace processes, as well as from personal interviews with the main actors of the peace talks, this section systematizes and analyzes the main approaches to peace(s) in Colombia. The analysis focuses mainly on the peace dialogue that took place between the government and the FARC (from 2012-2016) but also draws from previous narratives and practices that are still present in the public debate. The analysis of the discourses of peace are boiled down to four main approaches: a. Peace is understood as a relational dynamic that allows for the deconstruction of the friend-enemy binary and the recognition of the other; $b$. peace is seen as a condition that enables security and economic development; c. peace is re-signified through the floating signifier 'territory', to refer to the need of involving the locals in the definition and implementation of peace policies in order to truly take into account the needs of those living in the territories; and d. peace is proposed as the consecution of social and environmental justice, along with the possibility of an alternative development path that ensures the autonomy of indigenous peoples, black communities, and peasants to decide how they want to live and how they want to exist.

\footnotetext{
${ }^{3}$ See more on the idea of peace as an empty signifier in Rodríguez Iglesias, Ana I. (2020). 


\section{Peace as relational dynamic: In search for recognition}

The peace talks in Havana represented a starting point for the bridging of the abyssal lines that had deeply divided the different actors during the armed conflict - between those considered 'us' and 'them'. With the publication of the Agenda for Peace in 2012 and with the achievement of the Final Peace Agreement in 2016, the friend-enemy dualism was re-signified in several ways by Santos' coalition: the peace dialogues acknowledged the existence of the conflict, a conflict that is armed, political and social (FARC, 2012). That recognition came mainly from the government of Santos, but was strongly rejected by the former president Álvaro Uribe and his political party the Democratic Center, as well as by other opposition leaders from the Conservative Party, social sectors, and the Evangelical and Christian churches. Even within the government of Santos, some internal forces were against the political talks and maintained a belligerent language when referring to the armed group, such as was the case with the Minister of Defense - Juan Carlos Pinzón (López de la Roche 2015). Therefore, there was a hegemonic struggle in the public debate about keeping or transforming that enemy-friend dualism and the understanding of the war.

The acknowledgment of the armed conflict by the government of Santos also implied the recognition of the FARC-EP and the ELN as political actors: 'The process aims at putting an end to the armed conflict so that the FARC can transform themselves into a legal and unarmed political organization, they can become an actor in national civil life and they can receive democratic guarantees' (De la Calle 2012). For the guerrilla group this step implied the acknowledgment of their historical political claims. Little by little the language of both negotiating parties was less belligerent. Through mechanisms of confidence building both delegations started to leave behind the historical mistrust they had felt from each other. For instance, the government aided this by keeping the talks confidential and by not continuously airing controversies in the media, as well as by writing a very detailed text so that the FARC felt confident about every commitment in every point of the agreement. ${ }^{4}$ Another action that helped was the government changing the Minister of Defense in order to reinforce the peace discourse of the government as well as to ensure the renovation of the military leadership with pro-peace officers (López de la Roche 2015).

On their end, the FARC's discourse also evolved during the peace dialogues regarding their self-acknowledgment as victimizers and their willingness to beg pardon. For example, while during the launch of the peace talks in Oslo in 2012, the FARC leader Jesús Santrich replied "perhaps, perhaps, perhaps" when asked about their willingness to recognize their responsibility during the

${ }^{4}$ Interview with the government's chief negotiator Humberto de la Calle, Bogotá, 9 January 2018. 
conflict. By the end of the peace negotiations the armed group had carried out at least a dozen acts of begging pardon and they have continued to do so during the post-agreement phase.

Likewise, the peace talks and the peace agreement aimed to reconcile the state and the demobilized group with civil society. The government and the FARC considered it paramount that they involve civil society and the diverse peoples of Colombia in the peacebuilding phase in order to gain legitimacy among their stakeholders. Although the participation of civil society was restricted and constrained during the peacemaking process (Ríos and Cairo, 2018), the official discourse made by both sides was: that the victims were at the center of the Agreement; that women had been very vulnerable in the conflict and needed a differentiated recognition; that the black and indigenous peoples of Colombia had been allies for peace (breaking the hegemonic discourse that portrayed them as collaborators of the guerrillas) (Rodríguez Iglesias 2018, 2019); and that social and political movements, as well as political parties, had the right to exert opposition with guarantees and to not be criminalized when marching and exerting freedom of speech. In this vein, the Agreement acknowledges that peace is an issue that concerns the whole citizenry and that they have to participate from their territories and need to think about what peace means and entails there.

Despite the declaration of intentions of the text of the agreement, none of these new interpretations about the relation between us and them became hegemonic in the public discourse. It did, however, open the door for a possible resignification and it shook the parameters of the abyssal line. Still, despite this, strong forces within and outside the government continued to reproduce the same discourses that were disseminated over the previous decade that portrayed the guerrillas as the only victimizers and as being solely responsible for the 'narco-terrorism' that continues to siege Colombia.

\section{Peace as security and economic development: Consolidating the neoliberal state}

One of the prevailing discourses around peace that had prevailed throughout the 52 year long conflict in Colombia has been that of the negative peace. According to Galtung (1969), negative peace only deals with physical or direct violence, and neglects or denies the presence of structural and cultural violence. ${ }^{5}$ Many sectors of Colombian society, mainly within the establishment,

\footnotetext{
${ }^{5}$ In contrast, according to Galtung (1969) positive peace would be the absence of, not only direct, but also cultural and structural violence, understanding cultural violence as the ideological discourses that justify the physical and structural violence; and structural violence, as the institutional and system arrangements that (re)produced a state of domination, exclusion, and inequality. He contends that 
saw violence as an issue of public order and, therefore, equated peace with security. Lozano Guillén (2006) contends that the dominant class never had the will for peace and this is reflected in the language they have used in their official plans to defeat the 'subversives': 'scorched earth,' 'defense of national security,' 'strategy of war to win peace,' 'comprehensive war' and 'democratic security,' understood as a 'strategy against terrorism,' and an 'internal enemy', among others (2006: 46).

In fact, the securitized approach to peace that was implemented by President Álvaro Uribe (2002-2010) remained one of the main discourses that revolved in the public debate when the peace process started in 2012. The 'No' campaign for the 2016 Peace Agreement referendum was precisely led by Uribe and his political party which echoed the discourse of the previous decade of the need to defeat the guerillas. Uribe's Democratic Security Policy not only aimed at ensuring security, or a securitized peace, but also economic development. The logic behind this discourse of negative peace has implied maintaining the status quo of the political and economic elites by not recognizing the political and social roots of the conflict. In line with this, a large part of the establishment has seen the need to pacify certain territories of the country before proceeding with their modernization according to a neoliberal economic model that is based on extractive industries, mega-projects, and agribusiness (Grajales 2013).

Uribe's military approach was designed to contain two phases: a first phase aimed at recovering the control of the territories by the State, and a second phase to ensure the consolidation of territorial control through the improvement of citizen security and the implementation of an integral policy of human rights (Padilla de León 2008). The armed forces were enthusiastic about the determination of President Uribe to put an end to the guerillas via military means by by modernizing the armed forces. An important sector of the military had opposed the previous peace negotiations that took place under President Andrés Pastrana and they felt confident of this new approach that granted leadership to the army. Likewise, the economic elite was pleased with the new security approach and attributed the improvement of economic figures to it. For example, Luis Carlos Villegas, the Director of the National Association of Businessmen of Colombia, under Uribe's Presidency, said in 2008:

\footnotetext{
Although the good performance of the economy has been the result of good economic policies, likewise the advances in security and governability have translated into greater confidence of national and international economic agents, as reflected in an increase of national and foreign investment, greater consumption and, in general, in a stimulus of economic activity (2008: 36).
}

in order to achieve peace it is necessary to act in the three dimensions of violence at the same time because they are mutually reinforcing. To illustrate this, he used the image of a triangle of which each type of violence occupies a corner united in a continuum of violence (1969: 302). 
Villegas was then selected by Santos to act as the representative of businessmen in the peace process, and after a time in Washington D.C. as an ambassador, he came back to Colombia in 2015 to assume the charge of Minister of Defense. Both Villegas and General Mora shifted their support from a negative peace to a political solution through a peace process. The confidence they had in President Santos, who was the Minister of Defense in the second term of Uribe, and the incorporation of Villegas to the government, were key elements that were needed to mobilize the support of the military and business sectors during the latest negotiations.

The discourse of a securitized and neoliberal peace evolved into the narrative 'Peace, yes; but not this way' in the 'No' campaign against the Peace Agreement in the 2016 referendum. Uribe and his party - the Democratic Center - opposed the whole idea of political negotiations with the FARC, but given the massive international support for the political solution, their discourse was adjusted and they proposed a different kind of agreement that followed the logic of the negative peace. The No campaign leaders rejected the reformist approach of the agreement that created a transitional justice system with reduced and alternative sentences for the FARC members as well as the armed forces; cried-out against the possibility that the FARC got temporary assigned seats in the Senate and Congress; and totally opposed the fact that narcotrafficking be considered a political crime when used to finance the political fight. In other words, they proposed a Peace Agreement that secured guarantees for business and political elites, that reinforced private investments and private property in the rural areas; and that peeled the FARC off of any political ground. Instead they were offering them a simple Demobilization, Disarmament and Reintegration program, along with the provision of justice through the ordinary justice system (León 2016; Márquez et al. 2016).

Uribe also resorted to present himself as the defender of the 'good' peace, criticizing the Agreement as a 'coup d'état against democracy' (26 September 2015), a 'wounded peace' (23 June 2016), an 'illegitimate peace' (3 August 2016), and a 'claudication to terrorism' (1 October 2016). His discourse made an impression on the public and the 'No' campaign won the referendum by a small margin, contrary to what was expected by the government, the FARC, many sectors of civil society, as well as the international community. As a result, the government and the FARC had to sit down again to modify some points of the Agreement and they introduced several changes, although none of these affected the core pillars of the political and agrarian reforms. ${ }^{6}$

\footnotetext{
${ }^{6}$ Among other changes, the new version of the Agreement reinforced the principle of private property; it kept the Constitutional Court as the last instance to resolve the appeals of the transitional justice sentences and established that the Special Jurisdiction for Peace would no longer have foreign judges. With the new version, the political connectivity of drug trafficking would have to be interpreted in accordance to the jurisprudence and interpretation of the Constitutional Court. And the 


\section{Territorial Peace: Between a Reformist and a Locally-grounded Proposal}

Without defining what peace means, a priority of the Peace Agreement is that peace must be built with a territorial focus, as well as with differential, gender, and human rights focuses. Territorial peace is not a new concept and it has been a de facto approach that has been utilised by many communities in different regions where everyday peace practices are built and implemented locally (Courtheyn 2018; Gago 2018; Hernández Delgado 2016; Lederach 2018, 2019; Oslender 2010, 2026; McGee 2017; Masullo 2015). It as well has been the bottom line of many previous peace policies (López 2016). The Final Peace Agreement formally introduced this concept and since then it has become a common concept in the political debate. Yet, the interpretation of 'territorial' remained fuzzy in the Agreement (Cairo et al 2018: 2) and in the implementation of the agreement (Estupiñán 2018). Many interpretations of it have been circulating in the public debate (Cairo and Ríos 2019). The Peace Agreement defines it as:

The territorial-based approach of the Agreement requires recognition and consideration of the needs (economic, cultural and social), characteristics and peculiarities of Colombia's territories and communities, thereby guaranteeing socio-environmental sustainability. Furthermore, it involves implementing the various measures comprehensively and in a coordinated way, with the active participation of all citizens. All of Colombia's regions and territories will contribute to the implementation of the Agreement, with the participation of territorial-based authorities and the various sectors of society (Final Agreement 2016: 6-7).

Yet, both the government and the FARC understood the concept under different logics, as did other sectors of the political sphere (Ríos and Cairo 2018). For example, for the state, territorial peace has been present in the peace policies written since the 1960 s, understanding that the construction of peace requires not only the security of citizens but also the presence of the state at the territorial level. ${ }^{7}$ During the peace negotiations The High Commissioner for Peace - Sergio Jaramillo - defined territorial peace as:

It is about: building a model that combines the implementation of national reconstruction programs in the territories with citizen mobilization in spaces

gender perspective was further clarified in the text, making reference to the fact that women and men have different needs and had being differently affected by the conflict.

${ }^{7}$ It gets inspired from other previous territorial policies such as the Peace Laboratories in the Middle Magdalena Region, Barco's National Plan of Rehabilitation and the Consolidation Plans. Personal interviews with civil servants of the Office of the High Commissioner for Peace as well as with the Hight Commissioner for Peace Sergio Jaramillo, 2018.

Araucaria. Revista Iberoamericana de Filosofía, Política, Humanidades y Relaciones Internacionales, año 22, $\mathrm{n}^{\circ} 43$. Primer semestre de 2020. Pp. 99-117. ISSN 1575-6823 e-ISSN 2340-2199 https://dx.doi.org/10.12795/araucaria.2020.i43.05 
for discussion and participatory planning processes; shortening the distance between the State and communities in conflict zones, and between the members of the same society; and breaking the mistrust and forcing our own institutions to respond much better. It is to move from the vicious circle of war to the virtuous circle of peace. To the extent that people participate and institutions respond, civilians start to rely on institutions more and more, and the State takes root in the territory. That could be our definition of peace: channeling conflicts through institutions across the national territory (Jaramillo 2016: 16).

With the demobilization of the FARC, the government deemed it paramount to build a bridge of trust between the state and the communities, and therefore, citizen participation was a key element for the local ownership of peace programs and in making the state accountable for their fulfilment. Taking for granted that the state would respond, this dynamic would close a circle of confidence.

The exaltation of citizen participation is putting into practice the participatory mechanisms introduced in the 1991 Constitution. In this regard, territorial peace would imply the decentralization of the state and the consolidation of the state in the regions. This would also require understanding the state, not only as institutions, but also as the relations and norms that link the communities and the rule of law. The overall goal is to legitimize the presence of the state in the regions where it has been absent or inefficient. The territorial peace programs, according to Jaramillo, would be 'just an excuse', a vehicle or a means for that. ${ }^{8}$

The FARC's view on territorial peace differs from the state's administrative logic, as they conceive it to be based on the reinforcement of the territories as live entities that are recipient of social relations:

We, from the same Oslo discourse, proposed the need of a territorial approach for rural dynamics, because these are not merely about land as a physical object, but include socio-spatial relationships in the territory, the integrity of physical aspects that make up the territory as well as the communities that build the territory. Our struggle was for the territories, for the defense of peasant, Afro and ethnic territories. ${ }^{?}$

The guerilla's interpretation of territorial peace is based on their relationships with the communities in the territories that they interacted with during the fifty years of the conflict. Their view envisions the transformation of rural areas, not only through the distribution of land, but through access to material and non-material resources that secures the good living of the rural population. For many years the FARC's fight was no longer for land but for

\footnotetext{
${ }^{8}$ Personal interview with the High Commissioner for Peace Sergio Jaramillo and with Andrés García from the Office of the High Commissioner for Peace; Bogotá; 2018.

${ }_{9}$ Personal interview with Francisco Toloza, speaker of Voces de Paz in Congress; Bogotá, 28 April 2018 and 2 May 2018.
} 
territorial control and control of the dynamics taking place within a given territory. Thus, the armed group saw their role at the Negotiating Table as the vanguard of the peasantry, voicing their historical and new demands (FARC 2013). In that sense, they tried to gain a space in the implementation phase of the peace policies as co-implementors or co-supervisors, in a corporativist logic. This was something that was rejected by the government who understood that this was their role and not the FARC's. The government believed that the FARC members should reintegrate into civil society and should participate in the programs as regular civilians through the established participatory mechanisms, but not as part of the supervisors of the state. ${ }^{10}$

While the government put more emphasis in the concept of territorial peace during the negotiations, the FARC talked more about peace with social justice and sovereignty, what could be understood as territorial justice. At its core citizen participation was also deemed a key factor of the implementation:

Today we are giving the transformative power to the Colombian people, which we have built for more than half a century of rebellion, so that with it we begin to build the society of the future, that of our collective dream, with a sanctuary dedicated to democracy, social justice, sovereignty and relations of brotherhood and respect with the whole world (Márquez 2016).

The concept of territorial peace also implied different views in relation to the development model already in place in the regions and the rural reform that was proposed by the Agreement in its first point. The government was very emphatic from the beginning of the peace process about the red lines of the negotiation: 'I would like to remind the Colombians that here in Havana we are not negotiating the economic model or the military doctrine, among other issues raised by the FARC. We are clear about respect for foreign investment and private property' (De la Calle 2013). The peace talks were not the space to impose the 'revolutionary' peace the FARC intended or proposed in the public debate. The peacemaking process could be described as a reformist one within the neoliberal framework.

Peace, therefore, was expected to boost the economy, attract foreign investment, and reinforce private property through the titling of lands. Thus, the neo-extractive economic model of the recent governments of Colombia that had led to a reprimarisation of the economy (PNUD 2011: 37) was in confrontation with the peasant economy proposed by the FARC that was to act as complementary to and supplementary to other economic activities in the rural areas. A clear example of the clash between economic models was that the government simultaneously negotiated the Integral Rural Reform (Reforma Rural Integral, RRI) of the Peace Agreement and passed the Law

${ }^{10}$ Personal interview with Andrés García, High Commissioner Office for Peace, Bogotá, 12 April 2018. 
1776 of 29 of January of 2016 of Areas of Interest for Rural, Economic and Social Development (Zonas de Interés de Desarrollo Rural, Económico y Social, ZIDRES), ${ }^{11}$ which yields the use of public lands to national and foreign investments, and places peasants as being dependent on big companies, thereby creating a conflict between peasants and companies for access to uncultivated lands (De Sousa Santos 2017; Montáñez Gómez 2016). In short, as a member of the working team of the RRI Darío Fajardo put it 'they erased with the elbow what they wrote with their hands' (2018).

In addition, the National Development Plans of 2010-2014 and of 20152018 based the economic development of the country in mining-energy activities, fostering mega-projects to increase the exports of natural resources (PND 2011-2014). In this vein, Santos' government, through the Ministry of Mines and Energy, deployed a variety of legal instruments to favor and accelerate the allocation and development of oil, gas, biomass, and hydro projects (Esteban et al. 2015). The official rhetoric highlighted the value of those projects deemed to be of public interest by contending that they would contribute to the development of the country and to finance the peacebuilding phase (PND 2010-2014, 2014-2018).

The FARC instead proposed a peasant economic model, contrary to that of the global capitalist one, that provided rural people not only with land but also with the means to the use that land (training, technology, credits, subsidies, access to markets), and that protected small and medium family production. Their proposal of the agrarian reform in those terms drew from their Agrarian Program of 1964 (1993), but also included new claims related to the current economic order: the acknowledgement of peasants as political subjects; the formal recognition of the different peasant territories (Peasant Reserve Zones, agri-food and inter-cultural territories); limitations for the extractive industry; and regulation of mining, among others. The agreement did indeed include many of the reforms related to the provision of basic services to peasants (education, housing, health, water and sanitation, electrification, infrastructure, credit), while preserving the fact that the large latifundios (large estates), agribusinesses and extractive companies (mining, oil, biofuels) are untouchable. It also created a Land Fund for the distribution of three million hectares of land for peasants who currently live without or with limited-access to land, as well as a program of formalization of property. In addition, the Agreement establishes the need of an environmental and productive territorial plan. The FARC's acceptance of the twofold economic model for the rural areas, in which the agribusiness economy and the peasant economy coexist, was seen as a modernization and

11 This law was seen as a compensation to those economic sectors that opposed and feared the peace process as a way to calm their fears that the peace process would bring about a massive redistribution of land (Montáñez-Gómez 2016: 24)

Araucaria. Revista Iberoamericana de Filosofia, Politica, Humanidades y Relaciones Internacionales, año $22, \mathrm{n}^{\circ} 43$. Primer semestre de 2020. Pp. 99-117. ISSN 1575-6823 e-ISSN 2340-2199 https://dx.doi.org/10.12795/araucaria.2020.i43.05 
flexibilization of the FARC's discourse - mostly the result of the negotiations (Medina Gallego 2013).

In political terms, territorial peace implied: the democratization of the political system at the territorial level; incorporating the FARC's new political party - Revolutionary Alternative Common Force (Fuerza Alternativa Revolucionaria del Común, FARC); granting guarantees to social and political parties to exercise opposition; and fundamentally opening up spaces for the participation of citizens in the design, implementation, and monitoring of different peace programs.

Territorial peace remained a polysemic word with different tones whether used with the neoliberal logic of the government or the revolutionary approach of the FARC. How this diversity of territorial peace approaches are interacting in the peace implementation process depends on many factors, such as local conditions, the rapid response of the government to create confidence, and the control of illegal economies and related-violence, among others (Ríos and Gago, 2018; Harto de Vera 2018)

\section{Peace as alternative development, with social and environmental justice}

In the middle of the social and armed conflict there has existed a plurality of peasant, union, indigenous, and afro movements that have resisted both the FARC and the Government. Their resistance has been an act to defend their lives, their ways and means of living, their territories, their land, and their dignity. Through social resistance, these groups have: exerted a certain level of autonomy and self-government during the armed conflict; supplanted the state where the institutional state was missing (Weitner 2017); demanded their rights; and created bonds of solidarity (Rodríguez Iglesias, 2018). During the peace negotiations, these social groups understood that they needed to translate their own fights into a common language of excluded groups. Many of them came together to ask for a 'deeper' notion of peace, one that included their knowledges and experiences (Courtheyn 2018), and surpassed the logic of classes that had characterized the FARC guerrillas and the neoliberal logic of the different governments of Colombia.

The historical resistance of these various social organizations have had two points in common: to find a political solution to the war and the need to overcome the capitalist system of accumulation. With this common horizon in mind, in 2013 many of the peasant, ethnic, social and popular platforms organized a national mobilization for peace and joined the National Agrarian and Popular Strike that shut down many regions of the country from 19 August to 12 September in 2013. 
Out of the Agrarian strike, the Agrarian, Ethnic, Peasant and Popular Summit was born. Its mandate asked for a political solution to the armed conflict and reiterated their antagonist position towards the current economic model that had favored big land owners, agribusiness, and cattle ranchers. ${ }^{12}$

Many of these organizations had their own peace agendas that they had been developing during a long struggle and strong resistance against violence. Black and indigenous territorial organizations understood that they share a similar conception and experience of peace as well as a common struggle of resistance against the conflict, and as a result they decided to unite forces to press the government and the FARC to include them in the negotiations. As a result of a strong international lobby as well as a national campaign, indigenous and Afro-Colombians under the umbrella of the Ethnic Commission for Peace and the Defense of the Territories succeeded in getting invited to Havana and in getting an Ethnic Chapter included in the Peace Agreement the very same day the Agreement was signed (Rodríguez Iglesias 2018).

The negotiations in Havana triggered multiple activities, demonstrations, and mobilizations for peace and against violence (CINEP 2016). In order to advance a particular model of territorial peace, social groups developed several initiatives such as the Social Table for Peace; a Territorial Summit for Peace in the Afro-Colombian territories; the establishment of a Social MiningEnergy and Environmental Board for Peace; the proposal of an Environmental Truth Commission; an Alternative Urban and Popular Social Forum to ask for structural reforms; and the establishment of a Civil Society Board for Transparency in Extractive Industries, among others.

Likewise, of special interest was the sub-commission on gender that was created to introduce a gender perspective in the Agreements and to promote the participation of women in the process. This was a result of the mobilization of several feminist and women's organizations such as Ruta Pacifica de las Mujeres, Corporacón Humanas and Casa de la Mujer (Vargas and Díaz Pérez 2018).

The overall goal of these initiatives was to call attention to the negative consequences of the neoliberal model based on extractive projects in their territories. They denounced the violence caused by fumigations, bombings, arbitrary arrests, displacement, dispossession, and the pollution of their lands and water (CINEP 2012; Congreso de los Pueblos 2016). In this regard, they proposed that the peace accords included the recognition of and reparation payments for the environmental injustices that have taken place, as well as the transformation of the economic model, to make peace 'indeed' sustainable and based on the autonomy, sovereignty and world views of peasants, indigenous peoples and Afro-Colombians'.

12 Interview with the leadership of Agrarian National Coordinator and with the ONIC "s representative before the Agrarian Summit, Bogotá, 2018.

Araucaria. Revista Iberoamericana de Filosofia, Politica, Humanidades y Relaciones Internacionales, año $22, \mathrm{n}^{\circ} 43$. Primer semestre de 2020. Pp. 99-117. ISSN 1575-6823 e-ISSN 2340-2199 https://dx.doi.org/10.12795/araucaria.2020.i43.05 


\section{Conclusions}

This article argued that the interpretation of peace was at stake during the latest peace negotiations between the FARC-EP and the government of Colombia. The peace talks represented a meaning-making process through which different interpretations of peace came to light in the public debate. Although the two peace delegations reached a Peace Agreement on the minimum conditions to implement a series of peace policies, 'peace' as such remains a polysemic word, without a univocal interpretation. Rather, what peace means and entails is an open-ended debate that has remained during the aftermath of the Agreement such as during the campaigns for the referendum as well as in the latest presidential campaign in 2018.

Following a poststructuralist approach, this article has used discourse analysis and intertextuality as methods to systematize the four main discourses of peace that were floating around in the public debate in Colombia. Overall, peace is seen as a transition from war and therefore implies a change of discourse about the other. In that sense, peace means recognition for those who were excluded from society such as the guerrilla members and all those stigmatized as their collaborators (peasants, indigenous and Afro-Colombians, among others).

Secondly, peace in Colombia has also been predominantly sought after as a military defeat of the insurgent groups in order to ensure security and economic development. This approach has neglected the structural conditions that led to violence in the first place and it denies the need of structural reforms in the economic, social, and political fields.

A third main discourse of peace has focused on the territorial-based approach that the Peace Agreement develops. This approach, in general, implies that the implementation should be conducted in line with the will and the needs of local communities. In turn, the government of Juan Manuel Santos saw this approach as a way to build bridges of confidence between the communities and the State in order to legitimize the latter in the territories, while the FARC understood it to be the bottom-up consolidation of the life projects of the peoples in each particular territory and a way to legitimize itself as a new political force.

Finally, a variety of peasant and ethnic groups mobilized an alternative discourse of peace that entails social and environmental justice and that would allow for a different economic model, according to the needs and aspirations of the communities. This bottom-up approach asked for deep structural reforms to avoid the potential 'conflicts of the post-conflict times' that could arise given the prevailing extractive economic model that exists within their territories. 
This plurality of understandings of peace also relates to the plurality of understandings of the conflict, as well as to how to lead the peacebuilding phase. This discursive analysis around the multiple interpretations of peace and peacebuilding reflected in this paper has pointed out the difficulties ahead for Colombian society to reconcile, to reintegrate former combatants, and to overcome the structural violence that led to the armed conflict in the first place.

\section{References:}

CINEP (2016). Movilización por la Paz en Colombia: una infraestructura social clave para el posacuerdo. Centro de Investigación y Educación Popular. Bogotá: CINEP.

Agrarian Summit (2013). Declaración política de la Cumbre Nacional Agraria, Campesina y Popular. (https://viacampesina.org/es/colombia-declaracionpolitica-cumbre-nacional-agraria-campesina-y-popular/).

Cairo, H., U. Oslender, C. E. Piazzini Suárez, J. Ríos, S. Koopman, V. Montoya Arango, F. B. Rodríguez Muñoz \& L. Zambrano Quintero (2018). "Territorial Peace": The Emergence of a Concept in Colombia's Peace Negotiations. Geopolitics.

Cairo, H. and Ríos, J. (2019). Las élites políticas y la paz territorial en Colombia: un análisis de discurso en torno al Acuerdo de Paz. Revista Española de Ciencia Política, 50: 91-113.

Congreso de los Pueblos (2016). Hacia un nuevo modelo minero energético. Vida Digna, Periódico del Congreso de los Pueblos.

Courtheyn, C. (2018). Territories of peace: alter-territorialities in Colombia's San José de Apartadó Peace Community. Journal of Peasant Studies, 45 (7): 1432-1459.

De la Calle, H. (2012). Declaración de Humberto de la Calle, Jefe de la Delegación del Gobierno Nacional, durante la instalación de la mesa de conversaciones para la terminación del conflicto. (http://viva.org.co/ cajavirtual/svc0325/pdfs/articulo584_325.pdf).

De la Calle, H, (2012). Declaración del jefe del equipo negociador del Gobierno Nacional, Humberto de la Calle, antes de viajar a La Habana. (http:// www.altocomisionadoparalapaz.gov.co/procesos-y-conversaciones/ pronunciamientos-jefe-de-la-nacion.aspx).

De la Calle, H. (2013). Declaración del Jefe del Equipo del Gobierno Nacional para los diálogos con las Farc, Humberto de la Calle, desde La Habana, Cuba. (http://www.altocomisionadoparalapaz.gov.co/procesos-y-conversaciones/ pronunciamientos-jefe-de-la-nacion.aspx). 
De Sousa Santos, B. (2017). A Colômbia entre a paz neoliberal e a paz democrática. In: Santos, Democracia e Transformação Social. Bogotá: Siglo del Hombre.

Derian, J. D. and J. J. Shapiro (1998). International/Intertextual Relations: Postmodern Readings of World Politics. Lexington (Mass): Lexington Books.

FARC (1993). Programa Agrario de los Guerrilleros de las FARC-EP. (Programa Agrario de los Guerrilleros de las FARC-EP)

FARC (2013). 100 propuestas mínimas. Desarrollo rural y agrario para la democratización y la paz con justicia social de Colombia. (https://pazfarcep.org/pdf/100-PROPUESTAS-MINIMAS-1-PUNTO-AGRARIO.pdf)

Gago, E. (2018). ¿Cómo se articula la acción social en entornos de conflicto? El caso de San Basilio de Palenque. Araucaria. Revista Iberoamericana de Filosofia, Política y Humanidades (20)39.

Grajales, J. (2013). State Involvement, Land Grabbing and Counter-Insurgency in Colombia. Development and Change 44(2): 211-232.

Harto de Vera, F. (2018). Proceso de paz y desafíos regionales en Colombia. Araucaria. Revista Iberoamericana de Filosofía, Política y Humanidades (20)39.

Hernández Delgado, E. (2006). La resistencia civil de los indígenas del Cauca. Pap. Polit. Bogotá (11)1, 177-220.

Jaramillo, S. (2016). Prólogo. La imaginación para la paz. In: Jean P Lederach (Trans. T. Toda) La imaginación Moral. El arte y el alma de la construcción de la paz. Bogotá: Semana Libros.

Laclau, E. (2005). On Populist Reason. London: Verso.

Laclau, E. and C. Mouffe (1985 [2014]). Hegemony and Socialist Strategy. Towards a Radical Democratic Politics. Verso: London.

Lederach, A. (2017). "The Campesino Was Born for the Campo": A Multispecies Approach to Territorial Peace in Colombia. American Anthropologist (119)4, 589-602.

Lederach, A. (2019). Youth provoking peace: an intersectional approach to territorial peacebuilding in Colombia. Peacebuilding. (https://doi.org/10 .1080/21647259.2019.1616959)

León, J. (2016). Las apuestas de Uribe, Santos y las Farc (y sus riesgos). La Silla Vacía 10 October. (https://lasillavacia.com/historia/las-apuestas-deuribe-santos-y-las-farc-y-sus-riesgos-58282).

López, C. (2016). Adiós a las FARC. ¿Y ahora qué? Bogotá: Debate.

López de la Roche, F. (2015). El gobierno de Juan Manuel Santos 2010-2015:

Cambios en el régimen comunicativo, protesta social y proceso de paz con las FARC. Análisis político (85): 3-37. 
Lozano Guillén, C. A. (2006). ¿Guerra o Paz en Colombia? Cincuenta años de un conflicto sin solución. Bogotá: Ocean Sur.

Márquez, I. (2016). La más hermosa de todas las batallas. FARC-EP. 25 August.

Masullo, J. (2015). The Power of Staying Put: Nonviolent Resistance Against Armed Groups in Colombia. ICNC.

McGee, R. (2017). Invisible power and visible everyday resistance in the violent Colombian Pacific. Peacebuilding, (5)2, 170-185.

Montáñez-Gómez, G. (2016). Territorios para la paz en Colombia: Procesos entre la vida y el Capital. Bitácora (126)2: 11-28.

Mora Rangel, J. E. (2008). El Plan Patriota, base del Plan de Consolidación. In Armed Forces, Control territorial, legitimidad y consolidación de la Política de Seguridad Democrática (75)205.

Oslender, U. (2010). La búsqueda de un contra-espacio: ¿hacia territorialidades alternativas o cooptación por el poder dominante? Geopolítica(s): revista de estudios sobre espacio y poder, 1:1, 95-114.

Oslender, U. (2016). The Geographies of Social Movements. Afro-Colombian Mobilizations and the Aquatic Space. London \& Durham: Duke University Press.

Padilla de León, F. (2008). Editorial. In Armed Forces, Control territorial, legitimidad y consolidación de la Política de Seguridad Democrática. Publicación Militar Especializada de la Escuela Superior de Guerra de Colombia (75)205. PCDHDD. Plataforma Colombiana de Derechos Humanos, Democracia y Desarrollo

PNUD (2011). Colombia rural. Razones para la Esperanza. Informe Nacional de Desarrollo Humano 2011. Bogotá: INDH PNUD, Septiember.

Richmond, O. (2008). Peace in International Relations. Oxon: Routdledge.

Revista Semana (2014). Santos: "Colombia es hoy un país líder que evitó ser un Estado fallido". 21 November.

Ríos, J. and Cairo , H. (2018). Los discursos sobre la participación política en el proceso de paz de Colombia. Araucaria. Revista Iberomericana de Filosofía, Politica y Humanidades, (20) 39: 317-339.(https:// revistascientificas.us.es/index.php/araucaria/article/view/4910/4301).

Rodríguez Iglesias, Ana I. (2020). A decolonial critique of the liberal peace: Insights from peace practices of ethnic people in Colombia. Revista de Paz y Conflictos, 12 (2), 199-223. https://revistaseug.ugr.es/index.php/ revpaz/article/view/9379.

Rodríguez Iglesias, A. I. (2019). Las voces étnicas en el Acuerdo de Paz de Colombia: una resistencia ontológica. Revista de Relaciones Internacionales (39).

Rodríguez Iglesias (2018). Sentipensar la paz: Notas para la construcción de paz en Colombia desde las sabidurías de las comunidades étnicas. Iberoamérica Social 10. 
Rodríguez Pinzón, E. M. (2018). Los desafíos de la construcción identitaria del Estado para la paz: una aproximación desde el análisis del discurso. Araucaria. Revista Iberoamericana de Filosofía, Política y Humanidades (20)39.

Sánchez Iglesias, E. and V. Sánchez Jiménez (2018). La paz y la solución al problema del campo en Colombia: un análisis comparado entre el Acuerdo de Paz y el Plan Nacional de Desarrollo. Araucaria. Revista Iberoamericana de Filosofía, Política y Humanidades (20)39.

Uribe Vélez, Á. (2015). 'Acuerdo con las Farc es un golpe de Estado a la democracia': Álvaro Uribe. Elpais.com.co 26 September.

Uribe Vélez, Á. (2016). La palabra paz queda herida": Álvaro Uribe. Revista Semana 23 June.

Uribe Vélez, Á. (2016). Nuestra campaña por el NO: Uribe. 3 August.

Uribe Vélez, Á. (2016). La paz no es claudicar ante el terrorismo. El Mundo 1 October.

Vargas, J. and A. M. Díaz Pérez (2018). Enfoque de Género en el acuerdo de paz entre el Gobierno Colombiano y las FARC-EP: transiciones necesarias para su implementación. Araucaria. Revista Iberoamericana de Filosofía, Política y Humanidades (20)39.

Weitzner, V. (2017). 'Nosotros Somos Estado': contested legalities in decisionmaking about extractives affecting ancestral territories in Colombia. Third World Quarterly (38)5, 1198-1214. 
